\title{
November 2015: patent term extension: the Supreme Court of Japan gave an answer to the question and the JPO now has to prepare new examination guidelines
}

First draft submitted: 15 January 2016; Accepted for publication: 29 January 2016; Published online: 18 April 2016

Keywords: approval $\bullet$ Japan Patent Office $\bullet$ marketing authorization $\bullet$ patent term extension $\bullet$ PMDA $\bullet$ PTE $\bullet$ SPC in issue is $7.5 \mathrm{mg} / \mathrm{kg}$ (bodyweight) intravenous infusion and the interval is 3 weeks or more. As a matter of course, the patentee was required to obtain a new marketing approval from the Ministry of Health, Welfare and Labour for the new dosage regimen. The claims of the patent in issue are directed to a h-VEGF antagonist that is an anti-VEGF antibody. However, there is no claim element that is directed to the above-mentioned dosage regimen. Therefore, Genentech appeal to the Intellectual Property High Court of Japan (IPHC-J). The IPHC overturned the JPO's decision and held that the PTE application should be granted since the new drug approval in issue was required to sell the new product in the Japanese market and the patent was not able to work until the new drug approval in issue was obtained. In the decision held in May 2015, the IPHC-J presented a new standard as to how to judge whether a PTE application should be granted based on a new drug approval when there is an existing drug approval covered by a patent in issue, and criticized the JPO's 2011 revised Guidelines. The JPO appealed to the Supreme Court in 2015. The Supreme Court held that 'in the case where there are a disposal (e.g., drug approval) pertaining to the subject PTE application and an earlier disposal, as a result of comparing the two disposals are compared with respect to matters of exami-
Takeshi S Komatani Shusaku-Yamamoto, 17th Floor, Grand Front Osaka Tower, C 3-1 Ofuka-cho, Kita-ku, Japan tskomatani@shupat.gr.jp

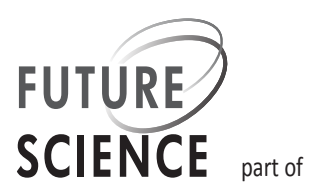


nation directly related to substantive identity of a pharmaceutical product, in view of the types and objects of a patented invention relating to the PTE application, if the manufacture and sale of a pharmaceutical product which is subject to the earlier disposal encompasses the manufacture and sale of a pharmaceutical product which is subject to the disposal pertaining to the subject PTE application, it is appropriate to interpret to recognize that the new disposal pertaining to the subject PTE was not necessary to work the patented invention relating to the PTE application.' In the subject case, it was necessary to obtain the new drug approval as the earlier approval does not cover products related to the new drug approval. The subject Supreme Court decision indicates how the examination should be conducted for similar cases. Currently, the JPO has revised the pertinent portions in the Examination Guidelines and has issued a new version in April 2016 [3].

\section{Disclaimer}

This commentary describes the opinions and observations of the author as a Japanese patent attorney and does not necessarily represent the viewpoints of the author's employers or author's firm. By its nature, the subject article provides the author's general opinion, and necessarily limited discussion of various topics; it does not purport to give specific legal advice or a substitute for legal counsel. As legal advice must be tailored to the specific circumstances of each case, nothing provided herein should be used as a substitute for advice of competent counsel. The author and the author's firm assume no liability for the use or interpretation of information contained herein. The author and the author's firm expressly disclaim all liability in respect of anything done or omitted to be done wholly or partly in reliance of this material.

\section{Financial \& competing interests disclosure}

The author has no relevant affiliations or financial involvement with any organization or entity with a financial interest in or financial conflict with the subject matter or materials discussed in the manuscript. This includes employment, consultancies, honoraria, stock ownership or options, expert testimony, grants or patents received or pending, or royalties.

No writing assistance was utilized in the production of this manuscript.

\section{References}

1 Courts in Japan (Japanese). www.courts.go.jp

2 Courts in Japan (Japanese). www.courts.go.jp

3 Japan Patent Office (Japanese). www.jpo.go.jp/shiryou/kijun/kijun2/h2803_kaitei.htm 